\title{
The Religions Zionist Sector at Bay
}

\section{Tamar Hermann}

Citation: Hermann, Tamar. 2022. The

Religions Zionist Sector at Bay.

Religions 13: 178. https://doi.org/

10.3390/rel13020178

Academic Editors: Amir Mashiach Isaac Hershkowitz and Enzo Pace

Received: 20 October 2021

Accepted: 28 January 2022

Published: 17 February 2022

Publisher's Note: MDPI stays neutral with regard to jurisdictional claims in published maps and institutional affiliations.

Copyright: (C) 2022 by the author. Licensee MDPI, Basel, Switzerland. This article is an open access article distributed under the terms and conditions of the Creative Commons Attribution (CC BY) license (https:// creativecommons.org/licenses/by/ $4.0 /)$.
Department of Sociology, Political Science and Communication, The Open University of Israel, Raanana 4353701, Israel; tamarhe@openu.ac.il

\begin{abstract}
In the last decades Religious Zionism moved from the margins to the center of Israeli society and politics. Members of this sector (RZS) are located today in top positions in Israeli politics, businesses, and among professional elites, academia, and the military, gaining growing influence over the national decision-making processes and policies. No wonder, then, that public opinion polls indicate that the members of the RZS are the most satisfied and optimistic in Israel today. The fact that the RZS is positioned mostly on one side of the political spectrum (Right), the tight interrelations within this sector and its widening periphery have further increased its national impact. It is argued here that this is a critical development in Israeli politics as this sector's members, and in particular those voting for the RZS parties, show relatively low commitment to core democratic values together with a clear preference for the Jewish aspect over the democratic aspect of the state of Israel. Furthermore, whereas in the past the RZS was politically represented by one main party (with some splinter groups coming and going), in the 2021 elections two parties (Yamina and the Religious Zionist Party (RZP)) collided head-on. For the first time each of these parties, the first more modernist and the second more fundamentalist, claimed to be the only authentic representative of this sector. The competition between them intensified when the election results showed that each of the two had gained the same number of seats in the Knesset, with the leader of Yamina unexpectedly becoming the new Israeli prime minister. It is argued here that the future balance of power between these two parties and their respective constituencies will determine the future of the RZS as a whole-whether it will establish itself as a pivotal actor in Israeli politics or remain at the margins.
\end{abstract}

Keywords: Religious Zionism; democracy; minority rights; coalition government; Supreme Court; Israeli politics; Israeli Arab citizens; Mafdal; Yamina; Religious Zionist Party; 2021 elections; Bennett; Smotrich; Ben Gvir

\section{“WHAT'S IN A NAME? THAT WHICH WE CALL A ROSE BY ANY OTHER NAME WOULD SMELL AS SWEET" (Shakespeare, ROMEO AND JULIET, CA. 1600)}

\section{Introduction}

Until early 2021 the terms "Religious Zionism" (in Hebrew Ha'Tziyonut Ha'Datit) or "National Religious bloc" (ha'machaneh Ha'Dati-Leumi) were alternatively used as umbrella terms for a distinct sector of the Israeli Jewish society ${ }^{1}$ — the one occupying the sociological and ideational space between the traditional (masorti) and the ultra-Orthodox (Haredi) categories in the religiosity scale. ${ }^{2}$ This sector as a whole (hereafter the RZS) is also widely known as simply "the religious" ( $h a^{\prime}$ dati'im), and its size is conservatively estimated to be around $16 \%$ of the Israeli Jewish population. As this article will argue, in 2021 the term attained a new content, reflecting a profound change in this sector that could modify not only its own status but the country's political landscape. ${ }^{3}$

The RZS is not homogeneous, but divided into at least three subsectors: the smaller modern-liberal religious group; the almost ultra-Orthodox, conservative torani (hardali) group; and the largest, supposedly mainstream, National Religious group (for a more detailed analysis of these subsectors, see, e.g., Hermann et al. 2014). Although these three subsectors differ significantly from each other in their respective worldviews and lifestyles, 
their members often live in the same neighborhoods or settlements, send their children to the same schools, sometimes even attend the same synagogue (for the very strong influence of the social networks within the RZS, see Kastman 2020), and by and large wear similar attire (for the correlations between Israeli Jews' electoral preferences and their levels of religiosity, see Yuchtman-Yaar et al. 2018; Cohen 2005; Cohen 2011). ${ }^{4}$ This is why for many years the RZS, despite those and other internal variations, could be politically represented quite successfully mainly by one party-Mafdal (Miflaga Datit-Leumit), established in 1956 following a merger between the Mizrahi Party and the Mizrahi Worker Party ( $\mathrm{Ha}^{\prime}$ Poel $H a^{\prime}$ Mizrahi). To be sure, there were always Religious Zionist individuals who voted for other parties, mainly Likud, but also the short-lived Sephardic party Tami, the Sephardic party Shas (established in 1982, first ran for election in 1984) or other, smaller, lists and parties. ${ }^{5}$ For a long time, the RZS and Mafdal went hand-in-hand, and the party was considered to be the political guardian of this sector's ethos and interests. Historically, the political ideology and agenda of Mafdal, which since 2008 became known as the Jewish Home ( $\mathrm{Ha}^{\prime}$ Bayit $\mathrm{Ha}^{\prime}$ Yehudi) Party, were neither radical nor fundamentalist from either the religious or political perspectives. ${ }^{6}$ Thus, in the first three decades of the state of Israel, its leaders could join-without much ideological hesitancy or constituency opposition-large coalitions headed by the Center-Left Labor Party, coalitions that also included openly left-wing, secular parties such as the socialist Mapam. After the 1967 War, however, Mafdal became the parliamentary home and political voice of the Jewish settlers in Judea and Samaria (on the effects of the 1967 War on the RZS, see Don Yehiya 2014; Sagi et al. 2018; Schwartz 2002). Later on, in 1977, when Likud came to power, it was almost natural for the party to join Likud-led coalitions under Begin, Shamir, Sharon, and Netanyahu. Indeed, with the growing national centrality of the RZS, the party(ies) ${ }^{7}$ representing it became a pillar of Likud-led governments, despite the continuing decrease in their number of Knesset seats from 1977 onward. ${ }^{8}$ In 2019, three Religious Zionist lists, the Jewish Home, the New Right (Ha'Yamin Ha'Hadash), and National Unity/Revival (Ha'Ihud Ha'LeumiTkuma), joined forces to create the next incarnation of Mafdal, namely, Yamina, headed by Naftali Bennett and Ayelet Shaked, ${ }^{9}$ both of whom had in the past been members of Prime Minister Benjamin Netanyahu's office staff and left because of deteriorating work and personal relations with their boss. ${ }^{10}$ In the next few years, Yamina underwent several splits and mergers, indicating the RZS's difficulty in acting in unison. However, the key rupture in terms of the discussion here took place right before the March 2021 elections: Yamina split in two when the National Union/Revival Party led by MK Bezalel Smotrich left it and agreed to form a technical bloc for the upcoming elections together with the Jewish Power (Otzma Yehudit) Party led by Itamar Ben Gvir, and Noam, a small new party formally headed by Avi Maoz but whose real leader was Rabbi Zvi Tao.

The partnership with Ben Gvir and his party came as a shock to many within the RZS, as Ben Gvir was widely known for his openly racist, anti-Arab views and activities, for which he had stood trial a few times in the past and which went beyond even Smotrich's rather radical, controversial views within the RZS on Jewish-Arab relations and Jewish supremacy in Israel. If this was not enough to shake the RZS, the new party took the name Religious Zionist Party (hereafter RZP), thereby proclaiming itself this sector's authentic representative while invalidating Yamina based on its allegedly too-compromised stance on issues such as the solely Jewish character of the state of Israel and the immediate need to annex the occupied territories. It should be noted that the new list was created following strong pressure on Smotrich by then-prime minister Netanyahu, whose relations with Yamina's two leaders had been allegedly strained for years, and who wanted to undermine the electoral power of the RZS. Netanyahu hoped that the creation of the new right-wing Religious Zionist list would pull the rug out from under the Bennett-Shaked electoral campaign and perhaps even stop their party from crossing the electoral threshold, leaving them outside the political scene for a while, as had occurred in the spring of 2019. The result of this move, as well as other developments in the electoral sphere, was utterly unexpected: while indeed the Bennett-Shaked party lost voters to the new RZP (each of them won seven 
seats in the Knesset), at the end of the day a "change coalition" government headed by none other than Bennett (whose parliamentary base is unprecedentedly small, a highly vulnerable situation for a prime minister) was established. The RZP, however, is not part of this new government. Smotrich and Ben Gvir refused to join it because an Arab party (Ra'am) is also a member of it. In other words, for the first time ever, two parties declaring themselves to be the authentic representative of the RZS are, (as of this writing) on the opposite sides of the fence: Yamina is in the coalition while the RZP is in the opposition. Furthermore, Bennett in particular is once again under attack by the RZP's leaders as a thief (of many RZS votes) and even as a traitor for compromising on the sector's core values.

Above and beyond the electoral results, the current situation appears to be a critical point in the history of the RZS. It signals an open political rift between the politically and religiously more moderate, who in most cases favor the Yamina Party, and the politically more nationalistic and religiously more fundamentalist, who favor the RZP. Although there is some correlation between this divide and that between the mainstream Religious Zionist and torani subsectors, it is by no means complete. The divide correlates even less with the settler-nonsettler differentiation within the RZS. The emergence of this unprecedentedly severe divide, which, as noted, has brought one representative body of the RZS to the helm of the government and the other representative body to the opposition, suggests that the historical common denominator of this bloc-the search for a balance between the Jewish and the democratic components of the state of Israel-is no longer consensual.

As background for readers unfamiliar with the Israeli political scene, the article first offers several explanations for the seemingly disproportional efficacy and visibility of the RZS minority in the life of the nation. Second, based on several sets of public opinion surveys, it explores the hypothesis that the RZS, as a whole, holds a unique set of views and values concerning the nature and operation of the Israeli democracy compared to both the ultra-Orthodox sector on one side of it on the religiosity scale and the traditional and secular sectors on the other side. Another hypothesis to be examined here is that the competition between the two Religious Zionist parties is not a regular power struggle over a common constituency, but rather a fierce fight over the direction of the RZS with regard to the appropriate relative weight of the Jewish and the democratic components of the state of Israel and its desired modes of operation. In this context, this article sets forth the unique positions of the RZS regarding the state of Israel and its regime compared to other sectors of the Israeli Jewish society, discusses the RZS' position on several core democratic values, and finally focuses on the differences between the RZP and Yamina voters in that regard.

\section{Methodology}

The discussion below is based on statistical analysis of questions that were included in a number of public opinion surveys. ${ }^{11}$ All surveys were based on representative samples of the Israeli population age 18 and above (although the original samples included both Jews and Arabs, and because this article examines the Jewish RZS, only the Jewish samples were analyzed). Sample sizes were from 500 to 1200 interviewees, depending on the specific project. Data sets include:

1. The monthly Tel Aviv University (TAU) and Israel Democracy Institute (IDI) Peace Index public opinion surveys (1994-2018). The interviews in this project were conducted via landline phones.

2. The IDI's annual Israeli Democracy Index surveys (2003-2021). Until 2018, all surveys were conducted via landline and mobile phone. Since 2019 they have used a mix of online panels and phone interviews for the sectors that do not use the internet for various reasons.

3. The IDI's monthly Israeli Voice surveys (2019-2021). These are mainly conducted online.

4. The IDI's biennial report A Conditional Partnership: Jews and Arabs, Israel 2021 (2017-2021).

Note: In Section 6 of the article the analysis examines only the RZS members who, in the last elections, voted for the sector's openly representing parties, namely, Yamina and the RZP. In other words, the data in this section do not include either Israeli Jews who 
define themselves as Religious Zionists but voted for other parties, for example, Likud, or non-Religious Zionists who voted for one of the sector's two parties.

\section{The RZS's Sources of Influence in a Nutshell}

According to Israel's Central Bureau of Statistics only about $16 \%$ of the Jewish population define themselves as RZ (or dati plus torani). Although apparently a small minority, the RZS's effects on Israeli society and politics are far more substantial than would be expected based on its demographic share. The most telling comparison is with the Israeli Arab minority, which constitutes around $22 \%$ of the total Israeli population and has much less impact on various walks of life in the country. For example, while RZS parties were always part of the ruling coalition, it was only in 2021 that an Arab party was invited to join the coalition and did so.

Several explanations may account for the RZS's efficacy and visibility. First, this sector has a large "periphery": a significant number of Israeli Jews who do not identify themselves as $\mathrm{RZ}$ in response to the question about their level of religiosity nonetheless affiliate themselves with this sector when asked about their sense of sociopolitical positioning (see Hermann et al. 2014; Finkelstein 2021). In fact, the Israelis self-affiliated with the RZS comprise about $22 \%$, significantly more than those simply defining themselves as RZ on level of religiosity. The RZS's "periphery" is composed of some ultra-Orthodox, many more traditionalists, and even a few seculars who identify with what is considered the overall RZS worldview and mode of operation, without necessarily sharing their religiosity. In focus groups conducted in the context of a 2014 study (the focus groups were conducted in the context of the project Hermann et al. 2014), the ultra-Orthodox participants who self-affiliated with the RZS said they wanted to be part of this sector because of its ability to combine religious life with modernity. The traditionalists explained their self-affiliation with the RZS by this sector's high social status, moderate religiosity, and "good manners", while the secular participants who affiliated themselves with the RZS mainly attributed it to this sector's right-wing political ideology, patriotism, and settlement activities.

Second, the RZS used to be quite politically homogeneous and had a widely recognized leadership group, a feature that, until recently, enabled it to act in unison. Apart from the ultra-Orthodox sector, the RZS was the most politically coherent sector in Israel, certainly more than the secular and the traditionalist sectors, so that compared to other segments of Israeli society it was fairly easily mobilized for political campaigns, such as the one against the disengagement from Gaza in 2005. However, past efforts to establish RZ parties with more centrist or leftist agendas failed. As Figure 1 shows, the RZS is the Israeli Jewish sector with the highest rate of individuals positioning themselves on the political Right; only few define themselves as centrists and even fewer as leftists (this trend is manifested, for example, in Navon 2021). ${ }^{12}$

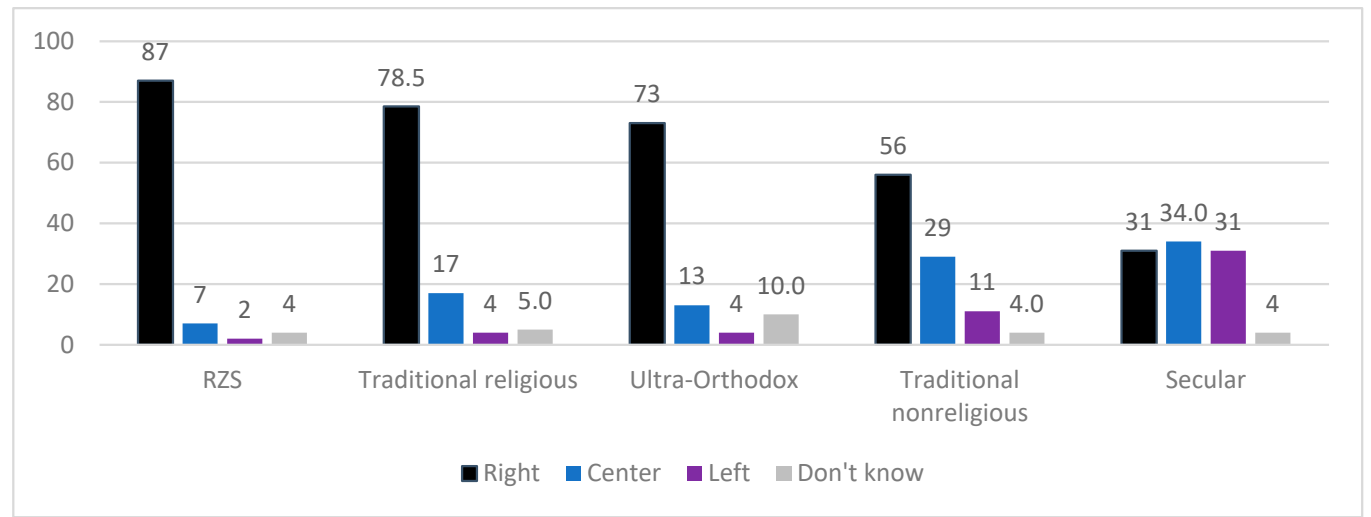

Figure 1. Political self-positioning by level of religiosity (\%). (Source: Israeli Democracy Index, 2003-2021). 
Moreover, as shown in Figure 2, the RZS's identification with the political Right has steadily increased over the years. Indeed, they are almost absent in the Center and the Left, and more interestingly, there is a slow decrease in the number of the "Don't knows".

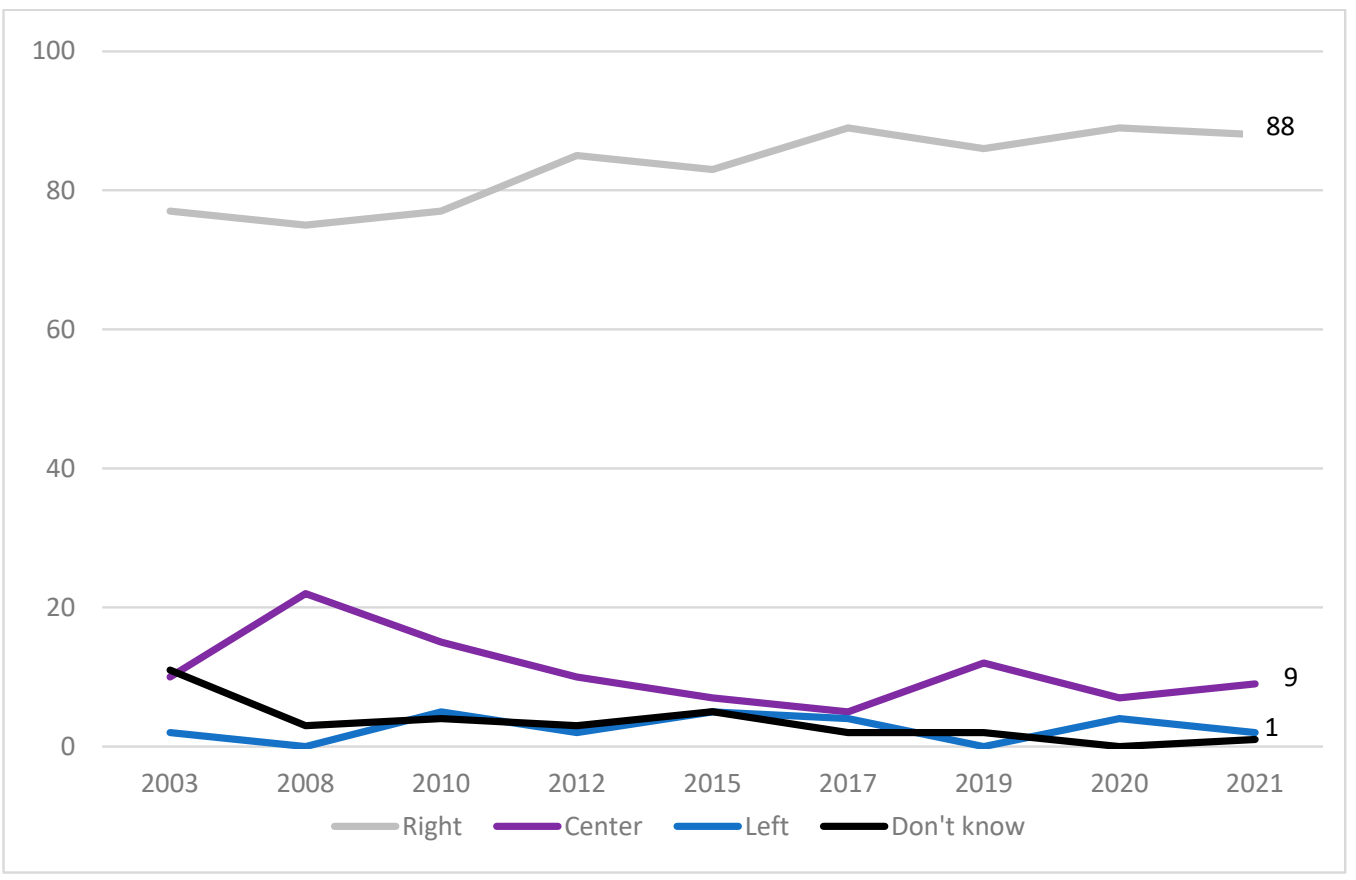

Figure 2. RZS political self-positioning, 2003-2021 (\%) (Source: Israeli Democracy Index, 2003-2021).

It is important to note here that, although the RZS is often identified in the public discourse with the settler community, empirically the percentage of RZS members living beyond the Green Line is close to that of the overall Israeli Jewish population, which is $7 \%$. It is true, however, that the relative share of RZS members among the settlers is higher than their share among the overall Israeli Jewish population (about one-third compared to $16 \%$ ). Furthermore, officeholders in settlement institutions are almost always RZS members (for example, from 2010 to 2012 Naftali Bennett, the present Israeli prime minister, was chairman of the Yesha Council). ${ }^{13}$

Third, the RZS has undergone a substantial change in aspirations since the 1970s. Beginning as a minority that had been mainly interested in preserving its way of life and securing its school system and religious institutions, it turned into a sector wishing-and succeeding-not only to integrate into the overall Israeli society but also to gain many national power positions in the economy and business spheres, professional occupations (medicine, law, accountancy, banking), the print and broadcast media, academia, the military, and elsewhere. In relatively few years, this reorientation has had a notable political effect: the sector's main political vehicle, the Mafdal Party, changed its self-perception and instead of being a sectorial party began to see and present itself as a national player, even though the number of Knesset seats it managed to win did not increase. Its leaders openly and repeatedly stated that they aimed to secure national leadership positions (see Kempinsky and Sandler 2020). Their favorite metaphor was and still is that they aspire to move forward from the railcar seat to the driver's seat of the train (for a comprehensive empirical study of the linkage between religiosity level and political views in Israel, see Pew Research Center 2016). ${ }^{14}$ This vision was translated into practical moves, assisted by the tightly knit network of the RZS communities and members who helped each other ascend the various professional and political hierarchies. 


\section{The RZS and the Israeli State and Regime}

This section discusses the RZS's assessment of various aspects of the Israeli state and Israeli democracy, as compared to other sectors of the Israeli Jewish society. Apparently, and at least partly because of the RZS's success in upgrading itself in recent years and its growing presence in national political and other power positions, thereby increasing its influence over various aspects of the public sphere, in general its members are less frustrated and more positive in their views of the state compared to other segments of the Israeli Jewish society, let alone of non-Jewish populations. To put it differently, because RZS members are involved in many policymaking processes and push quite successfully in directions favorable to their RZ constituency, they are more content with the outcomes of these processes than members of other sectors who feel their agenda is not so well served by their delegates.

The first question supporting the above indication concerns Israel's overall situation and is repeated in all Israeli Democracy Index surveys as the opening item: "How would you characterize Israel's overall situation today?" Throughout the years, the RZS members were always the most positive in their assessments. For example, in the 2021 Israeli Democracy Index, $44 \%$ of the RZS interviewees defined Israel's situation as good or very good compared to $39 \%$ of the ultra-Orthodox, $26 \%$ of both traditional groups, and only $23 \%$ of the secular. This general assessment correlates with a similar distribution of answers to another question about the quality of life in Israel: "Is Israel a good place to live?" (Figure 3). Although most Israeli Jews respond positively, the RZS has the highest rate of those assessing Israel positively. Interestingly enough, the secular sector, many of whose members belong to the political Left, is the least positive in this regard, with the smallest majority stating that Israel is a good place to live.

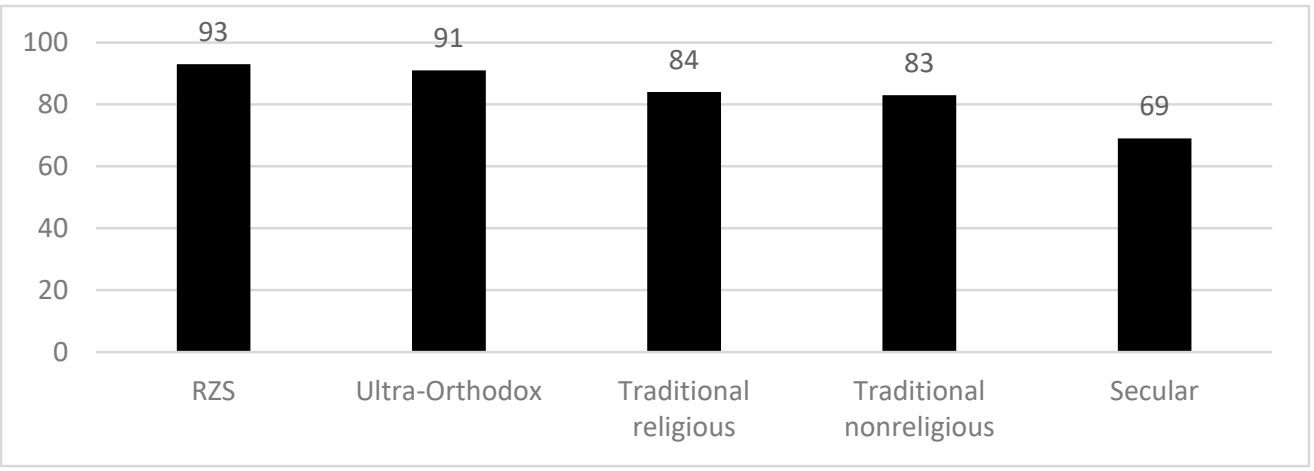

Figure 3. Agree that Israel is a good place to live, by level of religiosity (\%) (Source: Israeli Democracy Index, 2014-2021).

The same phenomenon can be seen in the distribution of answers to another repeated question that measures the interviewees' sense of belonging to the state of Israel and its problems. RZS members presented the highest rate of those feeling part of Israel and its problems, with the lowest rate found being among the ultra-Orthodox (Figure 4).

Another indicative question also asked in many Israeli Democracy Index surveys gauges Israelis' pride in their citizenship/identity as Israelis. As shown in the figure below, the share of the RZS that reported being proud of their Israeliness is the highest of all the religiosity categories (Figure 5). Once again, the ultra-Orthodox are the least proud to be Israelis, though we see an affirmative majority in this group as well. 


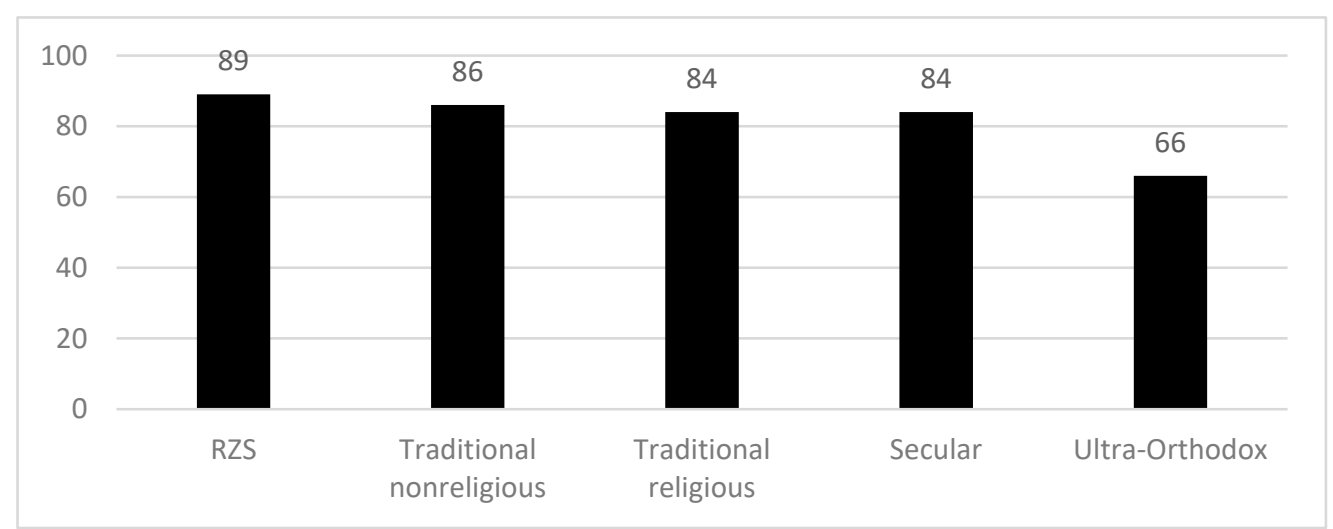

Figure 4. Feel part of the state of Israel and its problems, by level of religiosity (\%) (Source: Israeli Democracy Index, 2014-2021).

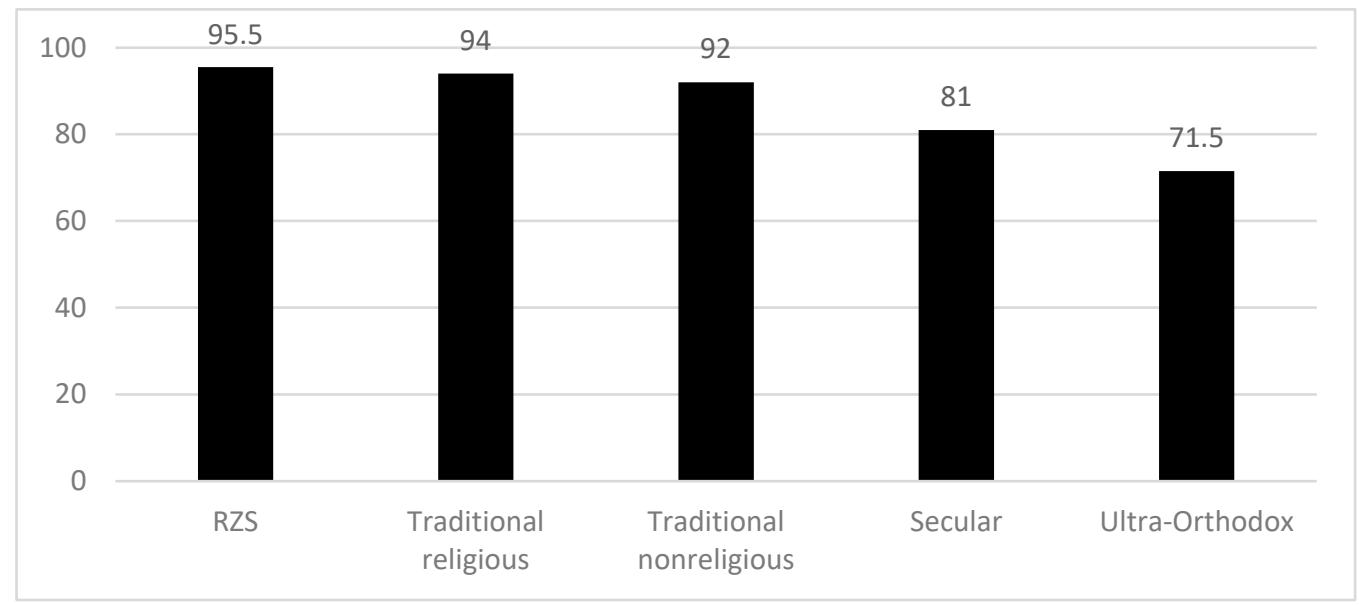

Figure 5. Proud to be Israeli, by level of religiosity (\%) (Source: Israeli Democracy Index, 2014-2021).

Furthermore, as Figure 6 indicates, RZS members are also the group most optimistic group regarding the future of Israeli democracy. Indeed, they are the only category with a majority of optimists on this topic, while the most pessimistic sector is the secular.

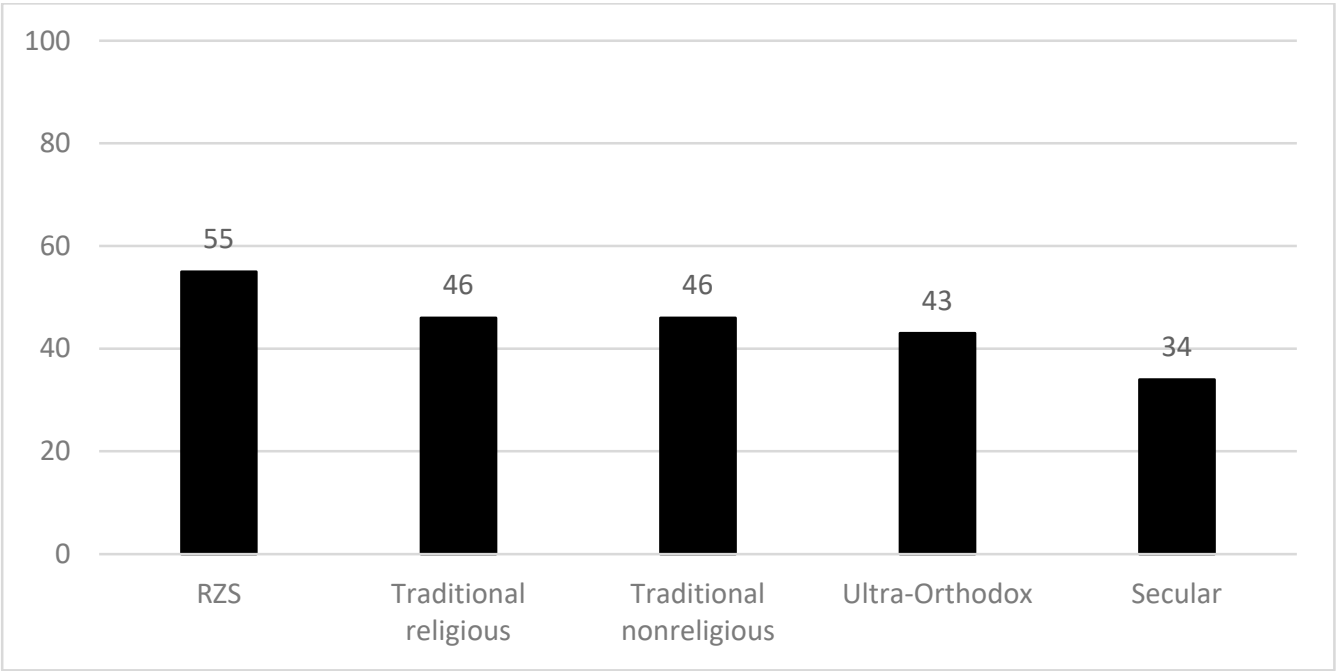

Figure 6. Optimistic about the future of Israeli democracy, by level of religiosity (\%) (Source: Israeli Voice Index, July 2020-July 2021). 
Regarding the balance between Israel's Jewish and democratic components, for every year of the annual Democracy Index results since 2016 (with the exception of 2019), at least a plurality of the RZS (in 2020 a small majority) has seen the democratic aspect as too dominant in Israel (Figure 7). Compared to previous years, in 2020 and again in 2021 a sharp decline occurred in the number of these who viewed the situation as balanced. It is notable that while the most common perception in the total sample was that the Jewish components are too strong, among the RZS only a small (and stable) minority holds that opinion.

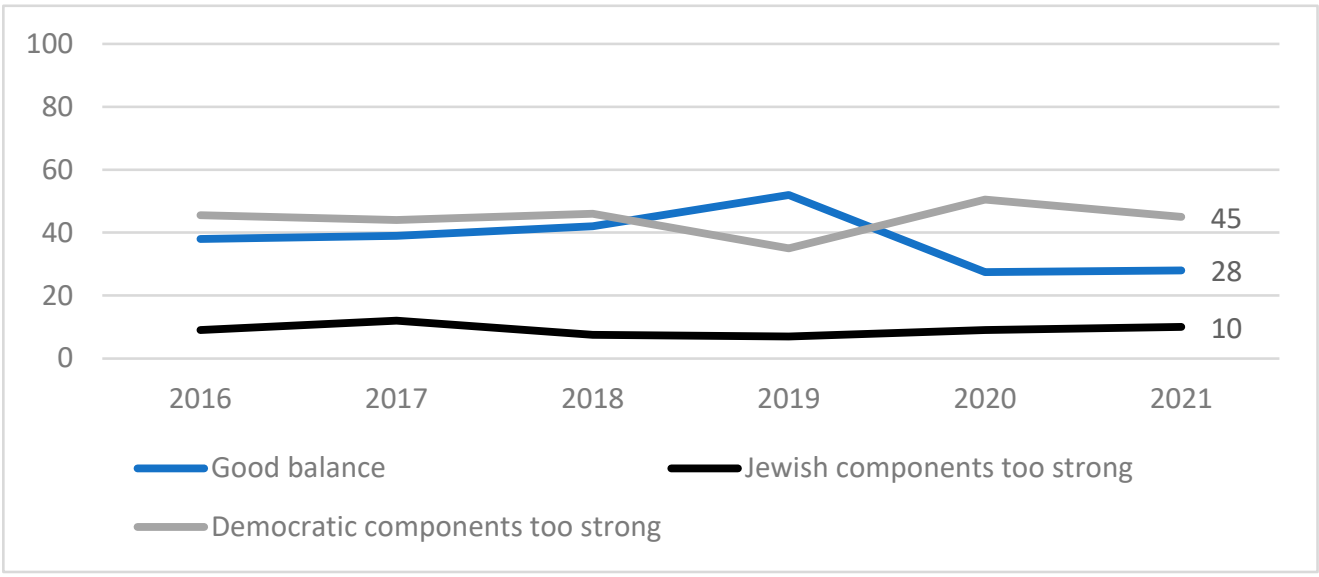

Figure 7. Feel that there is a good balance today between the Jewish and the democratic components of the state of Israel (\%, RZS) (Source: Israeli Democracy Index, 2016-2021).

The finding that the RZS views Israel's democratic components as too strong takes on a deeper significance when combined with the fact that the RZS (along with the ultraOrthodox group) presented the highest rate of those believing that the Israeli regime is democratic as far as the Arab citizens of Israel are concerned (Figure 8). In this case, the phrase "democratic for the Arab citizens of Israel as well" may have been understood by the RZS members who opted for this answer as negative from the standpoint of the Jewish majority group. As will be shown below, many group members aspire to curtail the civil rights of the Arab sector.

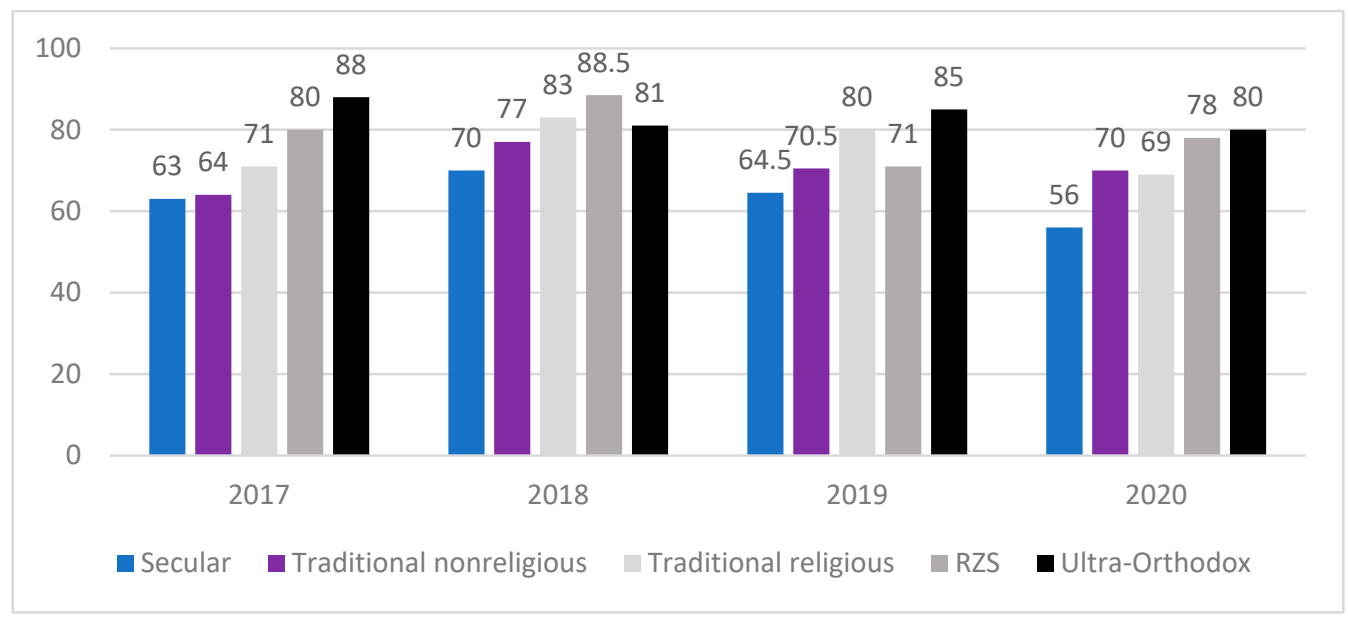

Figure 8. Agree that the Israeli regime is democratic for its Arab citizens, by level of religiosity, 2017-2020 (\%) (Source: Israeli Democracy Index, 2017-2020).

\section{Democratic Values}

The RZS is evidently quite satisfied with the Israeli state and its regime. But to what extent do they care about Israel's democratic performance? In other words, to what extent 
is this sector committed to democratic values, defined mainly by minority rights, and does it use them as a yardstick for its assessments of the state's political quality (for discussion of the linkage between religiosity and commitment to democratic norms, see Cohen and Lazar 2019; Ben et al. 2021)? As this section will show, in general RZS members have a low commitment to democratic values (for the tension between the RZS's commitment to the Jewish Halacha (religious code) and democratic norms, see Kaye 2013; Rubin 2014).

The values to be considered here are: equality (between Jewish and non-Jewish citizens of Israel), free speech, separation of powers, and the status of the judiciary.

At present, three-quarters of Israel's citizenry are Jewish, while the largest non-Jewish minority comprises the Arabs/Israeli Palestinians (about 22\% of the population at large and $16 \%$ of the eligible voters). However, since its first day as an independent state, Israel's majority-minority relations, under the shadow of the protracted violent conflict with the neighboring Arab states and the Palestinians, have not been simple. The two national groupings, while sharing the same (Israeli) citizenship, claim exclusive ownership over the same territory: the whole Land of Israel/Palestine, which both sides regard as their patrimony (somewhat surprisingly, in a 2021 survey conducted by the Israel Democracy Institute the Arab respondents were more open than the Jews to the option that the land belong equally to both peoples; see Hermann forthcoming). To make the situation even more complicated, while they are a majority within Israel, Israeli Jews are a small minority in the region - the Middle East, is mostly populated by often hostile Muslim Arabs, the brethren of the Israeli Arabs. Thus, the national majority is a regional minority, and a national minority feels part of the regional majority. This complication has been fueled by a prolonged series of full-fledged wars and smaller protracted armed conflicts, from which Israel indeed usually came out with the upper hand but not as a conclusive winner to the point that the conflict ended or that a permanent peace treaty was signed. Religion also plays a significant role in the majority-minority relations between Jews and Arabs in Israel. While the more secular segments of both the Jewish and Arab sectors see the tension between them as being related mainly to politics or territory, the more religious segments on both sides tend to view the conflict as additionally, or even mainly, religious. This situation gives these tensions another, apparently more persistent facet.

As shown by the Figure 9, RZS members tend to see the Jewish-Arab relations within Israel as more conflictual than the other sectors. In fact, they are the only sector in which a majority views this tension as the primary one.

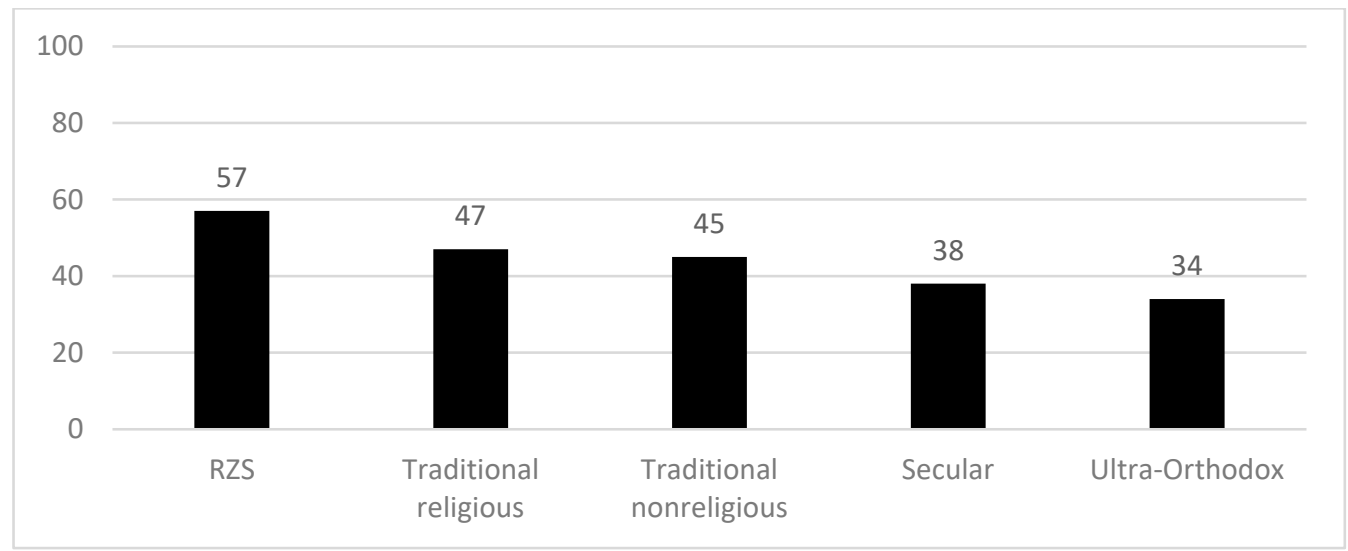

Figure 9. Consider the Jewish-Arab tension as the strongest of all national tensions, by level of religiosity (\%). (Source: Israeli Democracy Index, 2021).

Still, even under such circumstances, according to Israel's Declaration of Independence and a long series of laws, the democratic imperative of civil equality must be implemented. However, a majority of the RZS members do not see it that way. As the figure below indicates, the majority here (after the ultra-Orthodox and somewhat more than the traditional 
religious) believe that the Jewish citizens of the state should be granted more civil rights, mainly collective rights, than the Arab citizens (Figure 10).

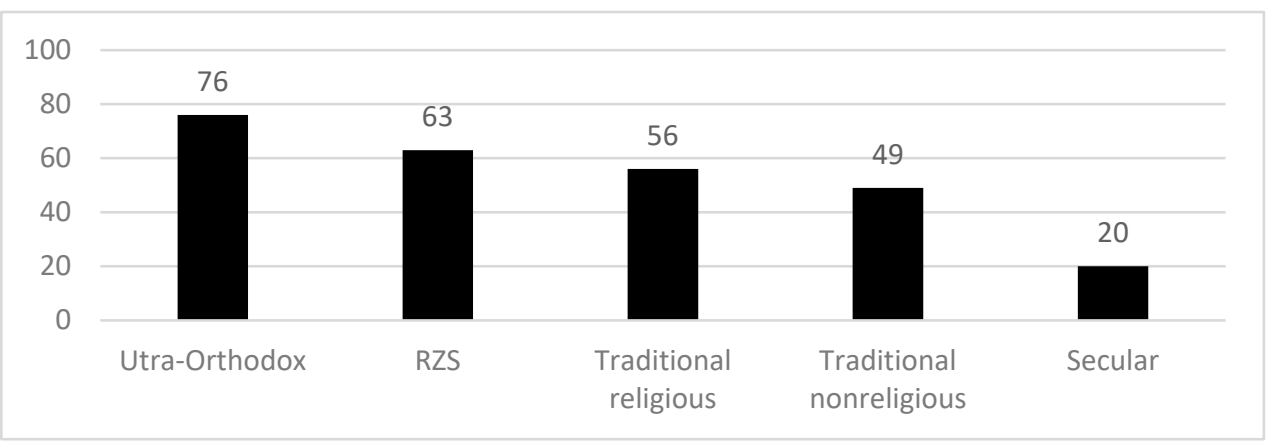

Figure 10. Agree that the Jewish citizens of Israel should have more rights than non-Jews (\%). (Source: Israeli Democracy Index, 2021).

Along the same lines, almost all RZS members (at the same rate as the traditional religious, who, as noted above, often serve as a "periphery" of the RZS) regard belonging to the Jewish religion as a critical prerequisite for being an Israeli, a stance that leaves practically no room for non-Jews in the Israeli collective (Figure 11).

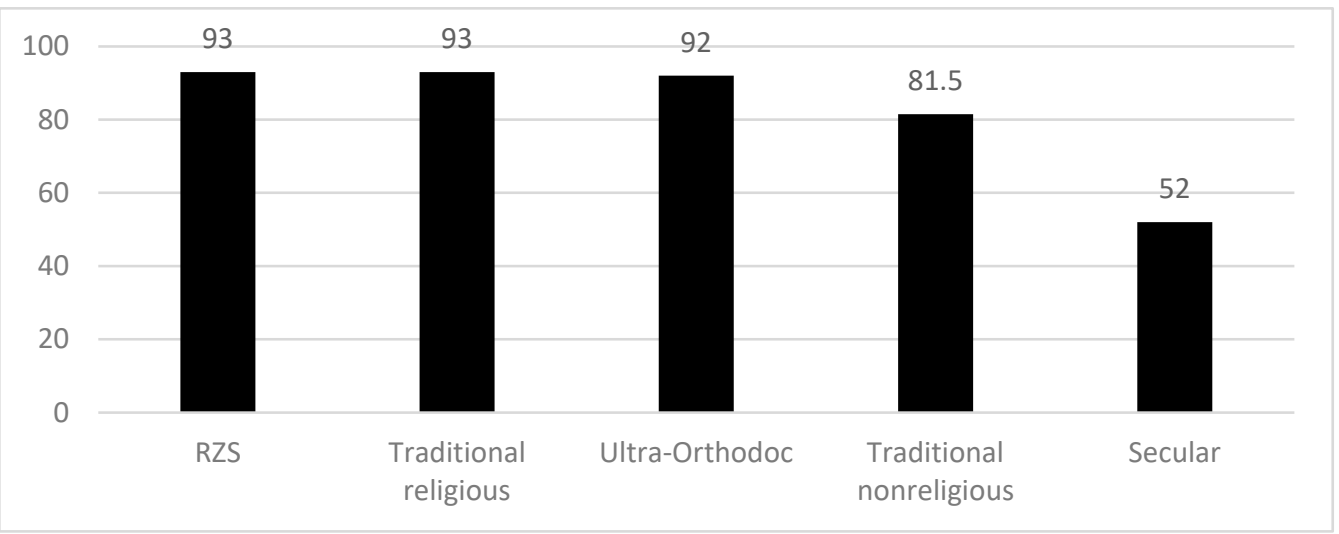

Figure 11. Agree that one should be Jewish in order to be an Israeli, by level of religiosity (\%).

The most critical issue in the context of a territorial conflict is the ownership of land. Hence, we asked several times to what extent Israeli Jews agree that Arab citizens of Israel should be allowed to buy land everywhere in the country like the Jewish citizens. As shown in Figure 12, the RZS is the category with the highest share of those asserting that Israeli Arabs should not be allowed to buy land anywhere in the country (other options were: to buy land everywhere; to buy it only in Arab towns and villages).

The previous findings go hand-in hand-with the following insight: of all the Jewish religious categories, among the RZS members the highest percentage of individuals think minority rights in Israel are overly implemented (Figure 13). 


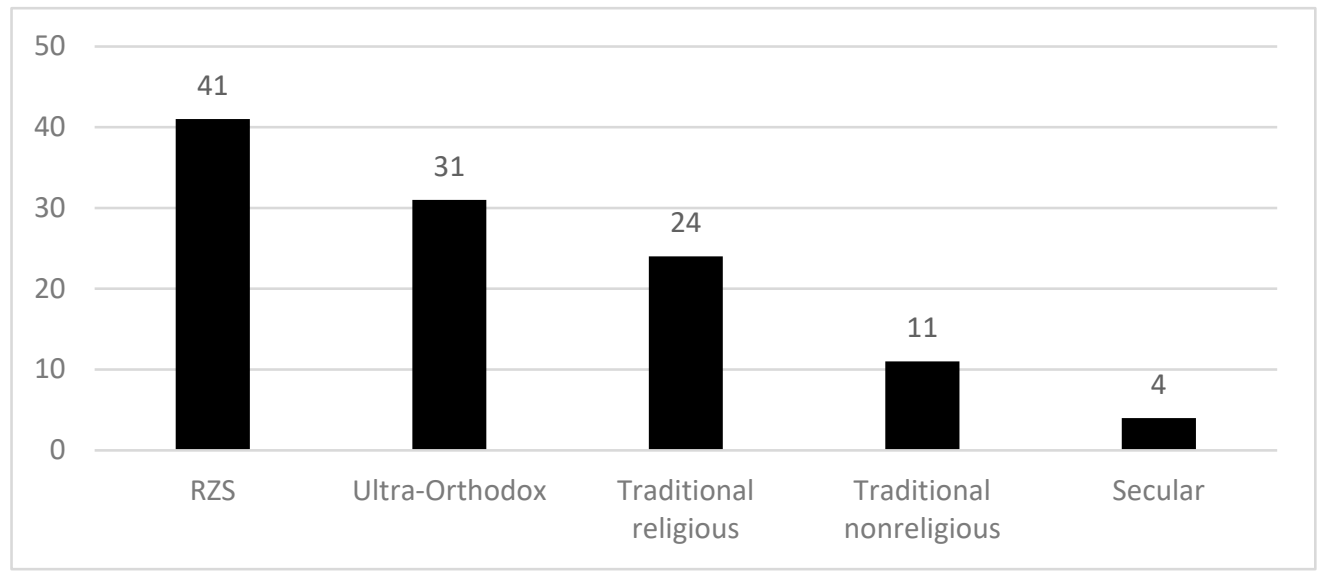

Figure 12. Agree that Arab citizens of Israeli should not be allowed to buy land anywhere in the country, by level of religiosity, (\%) Source: Tamar Hermann et al., A Conditional Partnership: Jews and Arabs, Israel 2021 (Hermann forthcoming).

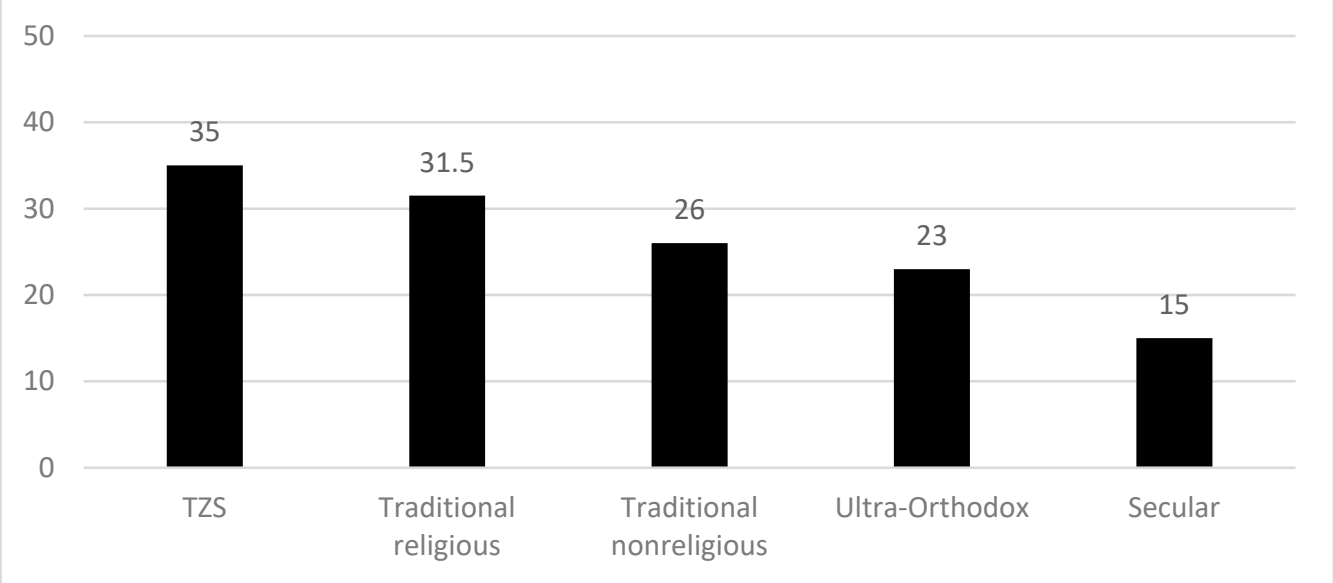

Figure 13. Agree that minority rights are overly implemented in Israel, by level of religiosity (\%) (Source: Israeli Democracy Index, 2021).

A similar distribution is found regarding the implementation of the basic democratic principle of free speech. As seen in Figure 14 below, the RZS is the sector with the highest rate of individuals who believe this principle is overly upheld in Israel.

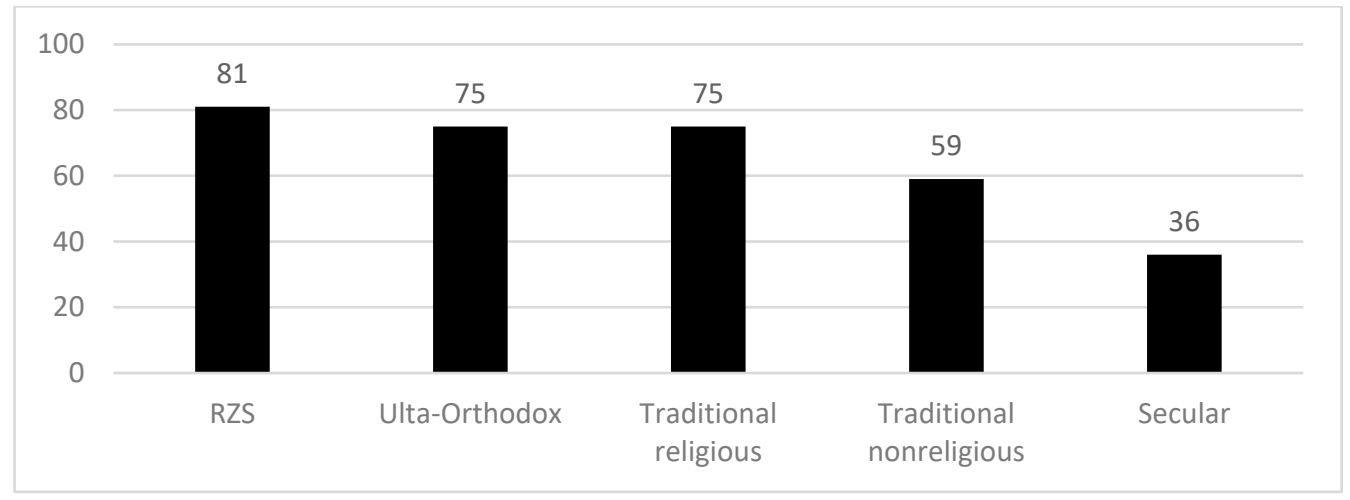

Figure 14. Agree that critical national decisions on society and economy should be made based on Jewish majority only (\%) Source: Hermann et al., A Conditional Partnership: Jews and Arabs, Israel 2021. 
Furthermore, the rate of RZS members agreeing with the statement that critical decisions on society and economy should be made based on a Jewish majority only, meaning that the Arab citizens of Israel should not be considered in this context, is the highest (Figure 15):

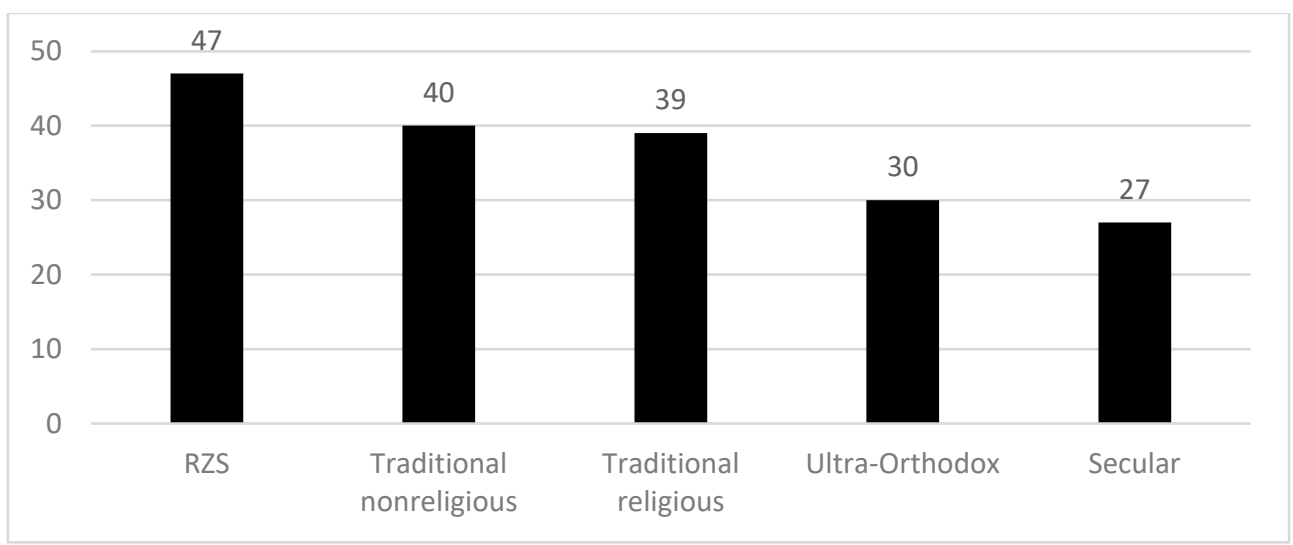

Figure 15. Agree that the free speech principle is overly implemented in Israel, by level of religiosity (\%) Source: Israeli Democracy Index, 2021.

The Israeli Supreme Court has been thought of for years as the bastion of Israeli liberalism. Hence its proper role is to be a central battleground between Left and Center on the one hand and the Right, with which most RZS members are affiliated, on the other. While the Left and Center support this institution and see it as the chief guardian of Israeli democracy, many on the political Right regard it as a ruthless institution that intervenes in the legislative and decision-making processes far and beyond its formal powers, thereby curtailing the elected government's ability to govern according to its worldview and agenda. ${ }^{15}$ Moreover, because the Supreme Court is where many appeals have been decided in the favor of Israeli Arabs and Palestinians from the West Bank, many on the political Right, including in the RZS, view the institution as a proxy of the political Left. As a result, as seen in Figure 16 below, their trust in this institution is low.

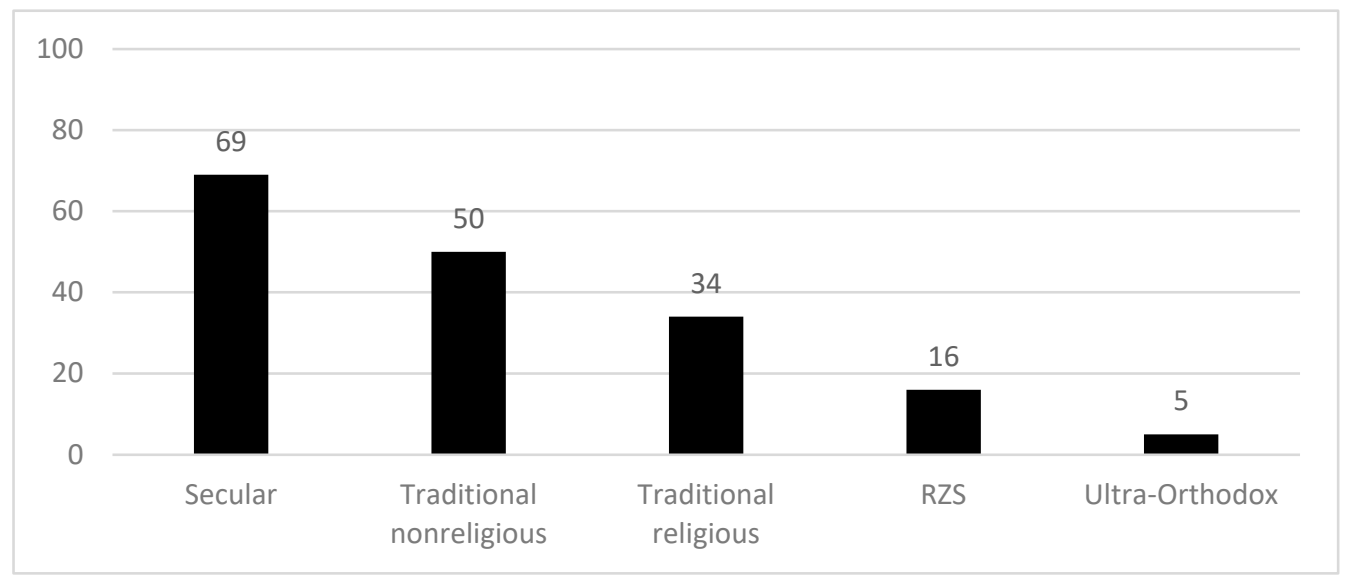

Figure 16. Have trust in the Supreme Court, by level of religiosity (\%) Source: Israeli Democracy Index, 2021.

In addition, except for the ultra-Orthodox sector, which conducts an ongoing struggle against the Supreme Court because they refuse to regard it as the country's highest judicial authority, the RZS has the highest rate of those assessing that the Supreme Court has too much power (Figure 17). However, unlike the ultra-Orthodox sector, the RZS challenges the Supreme Court not because of a religious refusal to accept its authority but because of 
what they consider its unpatriotic rulings-for example, regarding land-ownership cases in the West Bank. They also resent it, as noted, because they see it as constricting the government's room for maneuver and thereby appropriating its authority.

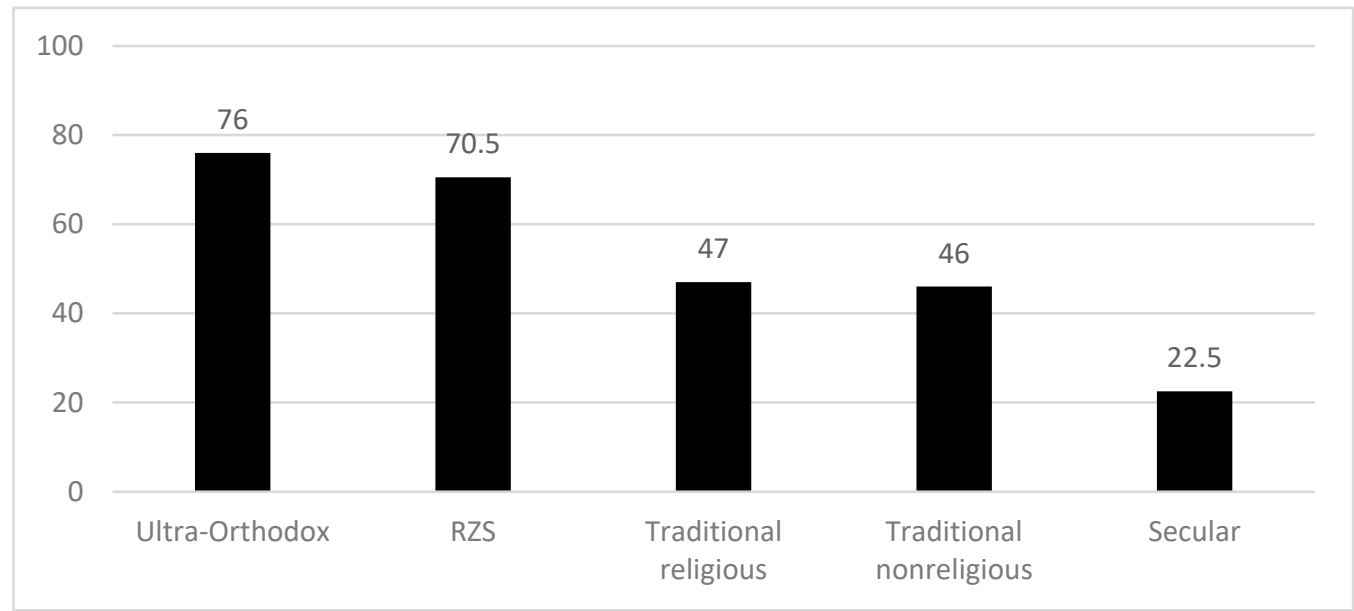

Figure 17. Agree that the Supreme Court has too much power, by level of religiosity (\%) Source: Israeli Democracy Index, 2021.

The considerable distrust and even resentment of the Supreme Court is most probably why the RZS, and of course the ultra-Orthodox, are the least open to the notion that the Supreme Court should have the authority to abolish laws made by the Israeli parliament when it finds those laws unacceptable from the democratic standpoint (Figure 18).

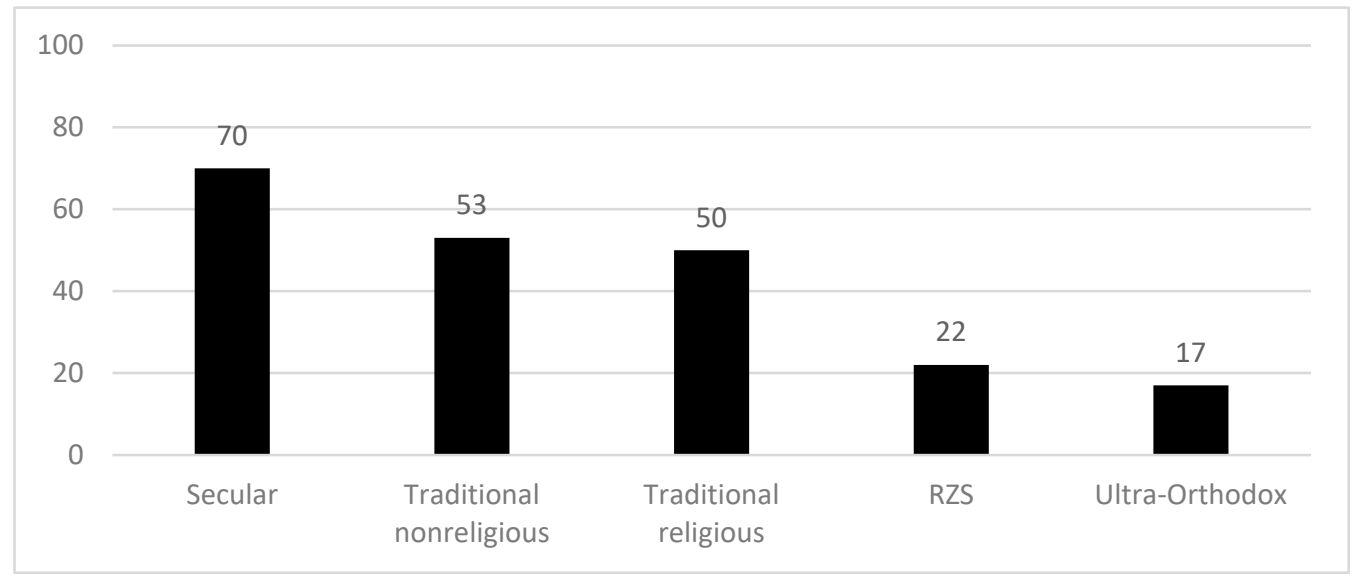

Figure 18. Agree that the Supreme Court should have the authority to abolish laws that were enacted by the Knesset if they were found to be impairing basic democratic values, by level of religiosity (\%).

\section{The Differences within the RZS}

As noted in the introduction, while in the past there was one party, or at least one dominant party, that represented the RZS ideology and interests, today two parties are competing over that status: Yamina and the Religious Zionist Party (RZP), both of which have seven Knesset seats. Thus, it seems a rift is developing in the RZS between its more fundamentalist element, represented by the RZP, and the somewhat more liberal element, represented by Yamina.

The data in Table 1 below are based on the interviewees' answers in the monthly Israeli Voice surveys to questions about their religiosity level and electoral choices, a segmentation of two questions that cannot be found in the formal publications of the election results. Clearly, in the 2021 elections, a new situation emerged, with the RZS now being politically divided into two subgroups almost equal in size. 
Table 1. RZS voting for RZS parties, 2019-2021 (\%).

\begin{tabular}{cc}
\hline April 2019 & $\begin{array}{c}\text { Union of Right-Wing Parties (URWP, headed by Rafi Peretz) } 34 \% \\
\text { New Right (headed by Shaked and Bennett) } 14 \%\end{array}$ \\
September 2019 & $\begin{array}{c}\text { Yamina + URWP (headed by Shaked) } 35 \% \\
\text { Jewish Power (headed by Ben Gvir) } 6 \%\end{array}$ \\
\hline March 2020 & $\begin{array}{c}\text { Yamina (headed by Shaked) } 43 \% \\
\text { Jewish Power 3\% }\end{array}$ \\
\hline March 2021 & $\begin{array}{c}\text { Yamina (headed by Shaked and Bennett) } 28.5 \% \\
\text { Religious Zionist Party (RZP) (headed by Smotrich) } 26 \%\end{array}$ \\
\hline
\end{tabular}

As noted, the rivalry between these two parties is not merely over the same constituency. They also espouse different national and sectorial agendas, influenced by their different perceptions of suitable ways to translate the RZS's commitment to Jewish religion and nationalism into practical platform and to integrate it into the Israeli political, social, and cultural arena. Although both parties are located on the Right side of the political spectrum, whereas RZP leaders have openly and repeatedly declared their faction's ultimate commitment to the Jewish aspect of the country, ${ }^{16}$ at least on the declarative level Yamina's leaders are equally committed to the Jewish and democratic value sets. Furthermore, the Yamina Party, headed by Bennett and Shaked, has carefully crafted an image as having a more modern-Jewish (albeit Orthodox, not Reform or Conservative), high-tech style, even being liberal on certain issues. The RZP, on the other hand, is straightforwardly hyperconservative and ethnocentric (some of its critics would even say racist) (for a critical reading of the RZP for its racist agenda and the composition of its leadership by an RZ author, see Andy 2021). In its platform the Yamina Party, which intentionally addresses all Israeli Jews, religious and secular alike, declares: ${ }^{17}$ "We believe that [Israel's] definition as a Jewish state does not contradict its definition as democratic. For us, the two elements are complementary". In the same inclusive spirit, they elaborate: "We reject coercive religious legislation as well as coercive secular legislation. We believe that every change in the status quo should be made based on dialogue and acceptance". As for the Arab minority, they say: "Israel is the only state in the Middle East which grants full civil equality to all its citizens and this is how it should be". Regarding the Supreme Court, they say: "We will act so that the reasons for intervention by the judiciary in governmental activities are limited to clearly unlawful cases, and not to general claims about reasonableness and proportionality". ${ }^{18}$

As mentioned above, he RZP was formed shortly before the 2021 elections and did not have enough time to publish a platform. Furthermore, out of fear that more than a few RZS members would not vote for the new party because of the partnership with Ben Gvir's chauvinistic faction, the joint endeavor was defined at the time as a technical bloc only. It should also be borne in mind that, in early 2021, the RZP was not a cohesive body but an ad hoc list composed of three partners that did not necessarily espouse exactly the same values, besides the shared understanding that they were all on the radical Right and wished to mobilize constituencies as large as possible, mainly of the RZS. And yet, the RZP's two leaders-Smotrich (who has served as a Knesset member since 2015 and as transportation minister in Netanyahu's transitional government in 2019) and Ben Gvir (elected as an MK for the first time in 2021)-have made numerous statements on political and social issues over the years that reflect their fundamentalist religious and political views. Both have argued time and again in favor of Jewish political and social exclusivity in Israel and have supported segregation between Jews and Arabs, from the two communities' places of residence to maternity wards in hospitals (see Douek 2016).

The first difference between the voters of the two parties is already manifested in their respective voters' self-positioning on the Left-Right continuum: about two-thirds (64\%) of the Yamina voters put themselves at the farthest right of the scale compared to $93 \%$ of the RZP voters. On a scale between $1=$ hard Left and $7=$ hard Right, the Yamina voters' score would therefore be 5.82 , compared to 6.40 for the RZP voters. 
Second, the RZP voters are allegedly "more patriotic", assessing Israel's overall situation as good or very good in higher numbers than the Yamina voters $(49 \%$ and $40 \%$ respectively) (Israeli Democracy Index 2021). The figure for the Jewish population at large on this question is $32 \%$, meaning that both subgroups are more affirmative than the general public in their view of Israel's overall situation but the RZP voters are significantly more positive. The same order is found in the two groups' answers to the question on the interviewee's sense of belonging to the state of Israel and its problems: in both cases, we found a large majority of those who "belong", but again, there is almost a full consensus among the RZP (96\%) compared to $87 \%$ among the Yamina voters. As for optimism about the future of the country, again the RZP voters show somewhat higher optimism than the Yamina voters (70\% and $67 \%$ respectively). However, a large gap emerges in the two voter groups perceptions of the existing balance between Israel's Jewish and democratic components (Figure 19). As the following figure shows, $65 \%$ of the RZP voters believe the democratic component is currently too strong, while only $27 \%$ of the Yamina voters hold that view.

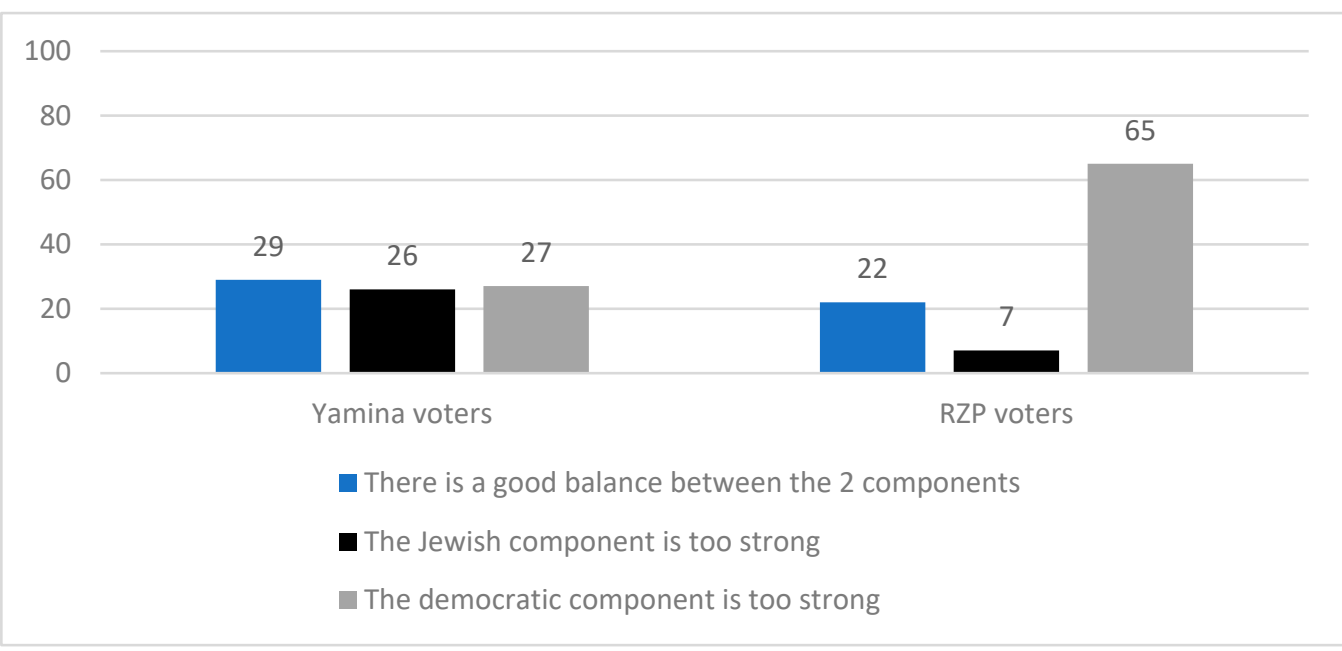

Figure 19. Israel is defined as a Jewish and democratic state. Do you feel there is a good balance today between the Jewish and the democratic components? (by voting in 2021, \%) Source: Israeli Democracy Index, 2021.

In addition, while a clear majority of the RZP voters support the strong-leader idea, only half of the Yamina voters are in favor of such a regime arrangement (Figure 20) (Hermann et al. 2021).

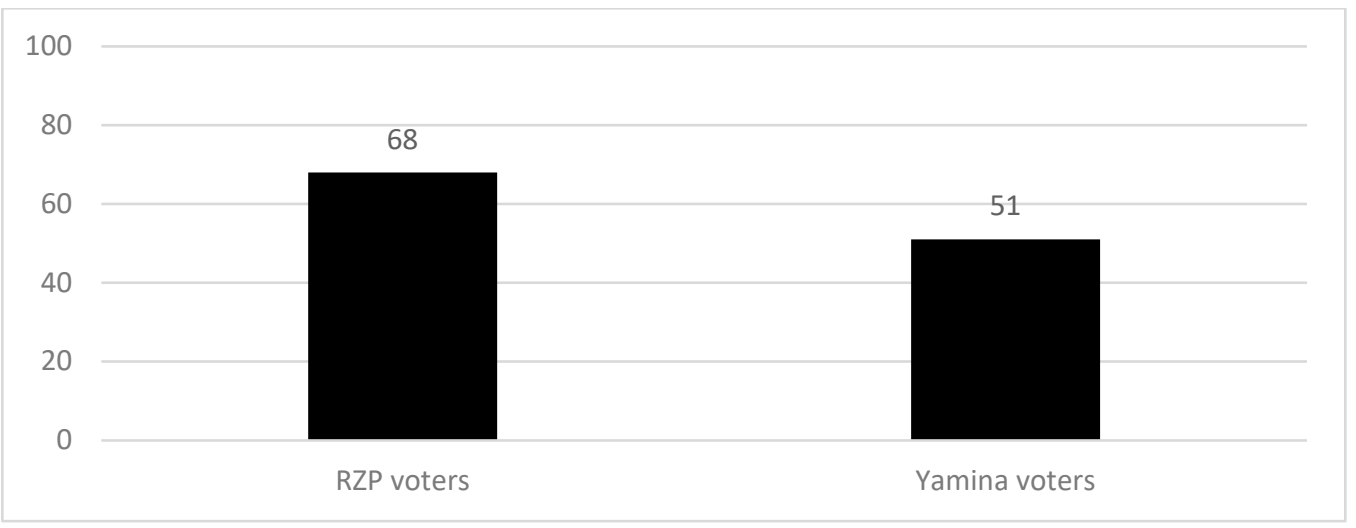

Figure 20. Agree that Israel needs a strong leader who will disregard the Knesset, media, or public opinion in order to deal with the special issues facing the country (by voting in 2021 , \%) Source: Israeli Democracy Index, 2021. 
A large difference between the two parties' voters was also found on the question of which tension is currently the strongest in Israel. While a considerable majority of the Yamina voters pointed to the Jewish-Arab tension, only $46 \%$ of the RZP voters did so; and $39 \%$ of the latter compared to only $18 \%$ of the former identified the Left-Right tension as the strongest. In other words, whereas for Yamina voters the main "we" and the "other" are the Jews vs. the Arabs, for RZP voters the main "we" and the "other" are to almost the same extent the Jewish political Right vs. the Left.

Another notable difference between the two parties' voters concerns their respective views about granting Jewish citizens more civil rights than non-Jewish-meaning Arabcitizens. While a plurality less than half of Yamina voters support such a discriminatory practice, a large majority of the RZP voters are in favor of it (Figure 21).

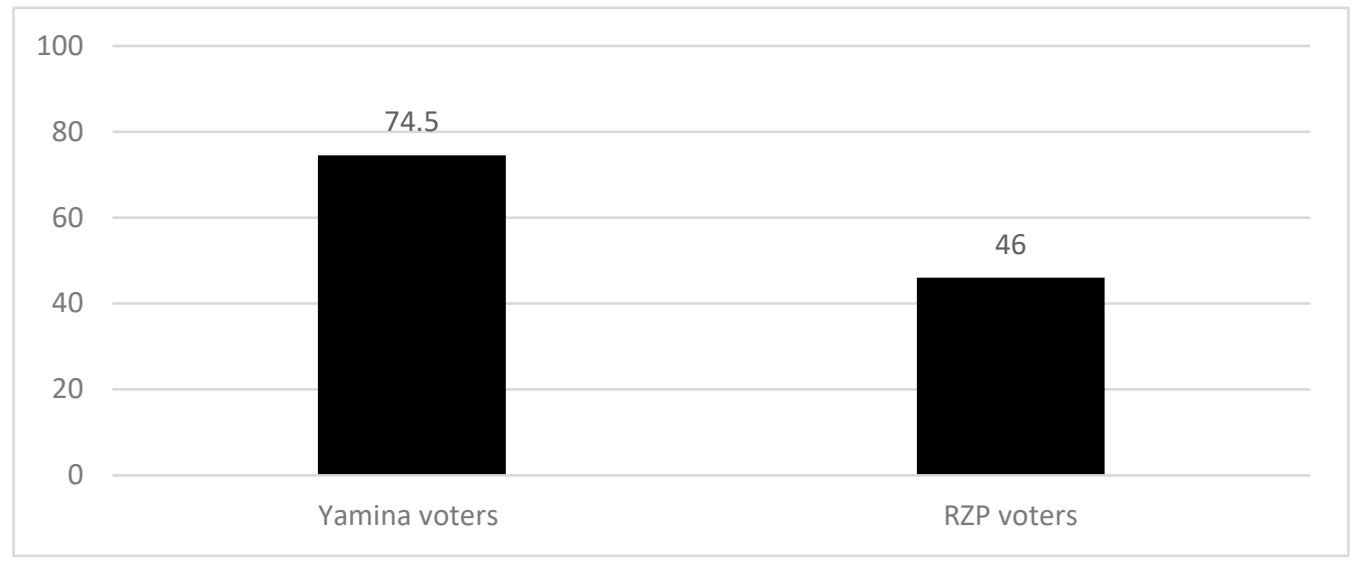

Figure 21. Agree that in Israel Jewish citizens deserve to have more rights than Arab citizens, by voting in 2019 (\%) Source: Israeli Democracy Index, 2021.

With regard to minority rights, again a plurality (40\%) of the Yamina voters believe they are overemphasized in Israel at present. Among the RZP voters, however, the majority $(53 \%)$ takes that view. In other words, the RZP voters would like to see reduced minority rights significantly more than Yamina voters.

On the issue of the Supreme Court, the two main RZP leaders have challenged its authority in the past. For example, following a 2021 decision of the Supreme Court, which in the past posted some strong critical comments on the Zionist endeavor, to allow an Arab woman who was a Labor Party candidate to take part in the Knesset elections and, Ben Gvir, who strongly opposed the ruling, stated: "In the upcoming elections the people of Israel have the chance to elect a strong right-wing government with strong Religious Zionism that will diversify the Supreme Court's composition and make the much-needed changes in the judiciary". ${ }^{19}$ In a press conference, Baruch Marzel, another leader of the same party, said: "The Supreme Court judges are the enemies of Judaism and of the state of Israel". ${ }^{20}$ Smotrich, for his part, asserted that "as the Supreme Court's authority is derived from that of the Knesset, unless the Knesset has authorized the Supreme Court, its decisions do not have to be obeyed". ${ }^{21}$ These statements reflect the outlook of their party's constituency; indeed both RZP and Yamina voters have little trust in the Supreme Court. However, whereas in the case of Yamina 23\% expressed trust in this institution, only $7 \%$ of the RZP voters did so. When it comes to the Supreme Court's intervention in the government's activities, admittedly both parties' voters agree that the court is overdoing it; among the Yamina voters, however, $80 \%$ think so while among the RZP voters the number is higher at $89 \%$. Furthermore, both parties' voters believe that Supreme Court judges act upon their political beliefs, that is, not out of their better professional judgment. Among the RZP voters, though, there is an almost full consensus on that point, a rare finding on a political issue (Figure 22). 


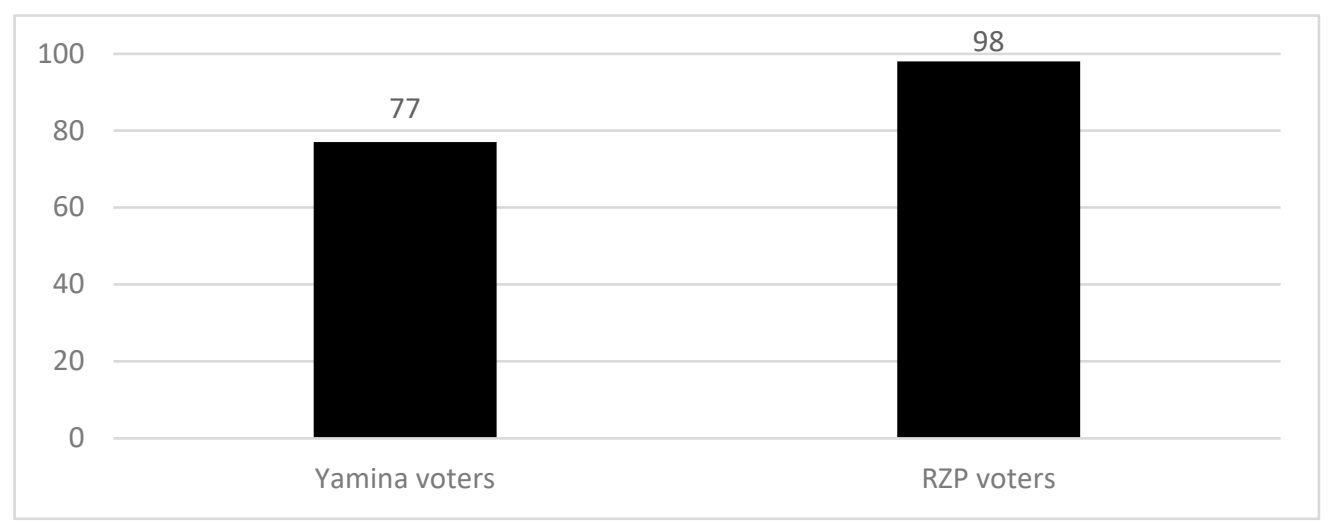

Figure 22. The Supreme Court judges act upon their political beliefs (by voting in 2021, \%).

\section{Discussion and Conclusions}

The larger and more influential a sociopolitical sector becomes, the higher the chances that internal splits over its agenda setting will emerge. This is what has happened in the Religious Zionist sector (RZS) over the past few decades and somewhat faster in the last few years. From a small and rather marginal and dependent sector, it has developed into a highly influential factor in the Israeli scene. This change was enabled by various developments: its demographic growth; the increased imbalance of power between the two main political blocs, that is, the dwindling of the Left and the expansion of the Right with which almost all of the RZS is affiliated; the upward mobility of many Religious Zionist individuals toward top positions in politics, the economy and business world, the media, the high-tech industry, academia, and the military; and last but not least, the gradual expansion of its periphery, mainly in the traditional-religious and nonreligious sectors, but also to some degree even in the secular sector. These more objective developments were accompanied by the RZS leaders' open and frequent calls for its members to integrate into the general Israeli society-mainly, but not only, in the IDF and the media (see Sadan n.d.).

As shown above, compared to other segments of the Israeli Jewish public, the RZS at large is politically quite homogeneous. Furthermore, its members are more satisfied with life in Israel. More than other groups, they are optimistic about its future, feel part of it and its problems, and are proud of being Israelis. They are also heavily invested ideologically in the Right side of the political spectrum and openly attribute much importance to Israel's Jewish components compared to its democratic components. Hence, they are more open to the idea of a strong leader and also more prepared than others (besides the ultra-Orthodox segment) to curtail or limit the civil rights of the Israeli Arab minority. In addition, this sector views the Supreme Court as an institution with much suspicion, often seeing it as a proxy of the liberal, secular sector.

All these shifts indeed empowered the RZS until, unexpectedly, after the 2021 Knesset elections and because of a unique constellation, it went as high as it possibly could: one of its major politicians, Naftali Bennett, the head of the Religious Zionist Yamina Party, was able for the first time ever in the history of this sector to become Israel's prime minister. His readiness to form a coalition not only with Zionist parties of the Center and the Left but also with an Arab party, an unprecedented move in Israeli politics, sparked strong negative reactions within the RZS, particularly among its leaders (see The Times of Israel 2021).

On the one hand, then, the RZS thereby achieved a seemingly unachievable goal. Yet, on the other hand, the expansion and empowerment of this sector also brought in its wake some less positive developments: new political actors, mainly the RZP, purporting to "properly" represent the sector emerged, entered the electoral and ideological arena, and intensified the internal power struggles occurring at both the elite and grassroots levels. Thus, even with the RZS's relatively high ideational homogeneity, 2021 saw an unprecedented development: two RZS parties competed in the Knesset elections and won the same number of seats, that is, a similar number of voters gave each of them their ballots. 
Hence the question, the answer to which is unclear at the time of writing, is: is the RZS still unified? As clarified in the last part of the article, despite their shared background, the two RZS parties' voters have significantly different views. Very much like their respective leaders, Yamina voters are somewhat more liberal or "soft" Right, while RZP voters are hard-liners on almost all counts. Such a situation is potentially hazardous to the unity of the RZS and hence also to its future political prospects.

\section{Postscript}

The classic approach of political science scholars, and hence of articles, is to avoid making any "prophecies". However, in this case, as the future of the RZS as a focal political actor seems to be unknown at present, the temptation to predict how things will unfold is too strong to resist. From here onward, several developments could occur: support for Yamina could dwindle either because of the existence of a more purist version of the RZS agenda - the RZP, or because Yamina's leaders are seen by more than a few RZS members as "traitors" for agreeing to join a mixed—soft Right, Center, and Left-coalition while the RZP leaders preferred to stay in the opposition on ideological grounds. Alternatively, if this coalition currently headed by Bennett survives for several years, possibly even until the next elections, and Yamina's leaders can offer convincing proof that they have well served RZS causes, the voters could shift in their direction. A third, and perhaps more likely, scenario is that the RZS will come close to splitting. In that case, it is expected that, in the post-Netanyahu era, Yamina will merge with Likud, the largest right-wing party whose voters have for years included many Religious Zionists. If that happens, the RZS, represented politically by the RZP, will in a sense be back to where Mafdal started: a minority social and political entity with only limited impact. Given this party's rather fundamentalist nature it seems unlikely that it will prove attractive to other sectors in Israeli society.

Only time will tell if the RZS sector will remain united, split and expand its influence via two parties, or return to its marginal, parochial niche.

Funding: This research received no external funding.

Institutional Review Board Statement: Not applicable.

Informed Consent Statement: Not applicable.

Data Availability Statement: Not applicable.

Conflicts of Interest: The author declares no conflict of interest.

\section{Notes}

The author is grateful to Mr. Yaron Kaplan and Dr. Or Anabi of the Israel Democracy Institute for their help in the statistical analysis.

The Israel Central Bureau of Statistics (CBS) scale for the Jewish population in general comprises five categories: secular (45\%); traditional and not so religious, plus traditional religious (25\%); religious and very religious (16\%); ultra-Orthodox religious (14\%). Because of the five categories' different age compositions, for the ages 18 and above the numbers are somewhat different: secular-43\%, traditional-30\%, religious-15\%, ultra-Orthodox-12\%. https://tinyurl.com/4bdjd78x, (accessed on 20 December 2021).

3 The Israeli Jewish religiosity landscape was explored in the three consecutive Guttman-Avichai surveys of 1991, 1991, and 2009, which were published as research reports by the Israel Democracy Institute (Jerusalem). For the 2009 report in English, published in 2011, see https:/ / en.idi.org.il/media/5439/guttmanavichaireport2012_engfinal.pdf, accessed on 14 February 2022.

4 The male members of this sector usually wear knitted kippas (skullcaps), which are easily distinguishable from the ultra-Orthodox cloth/plush kippas and hats. The female members wear head covers (usually some kind of scarf), although these are much more diversified than the men's head covers, and again are very different from the ultra-Orthodox women's cloth head covers or wigs.

5 For example, in 1984 a splinter group of Mafdal named Morasha participated in the national elections and won two seats in the Knesset. In 1986, its main leaders returned to Mafdal and in 1988, the party ceased to exist.

6 The three ideological pillars of the party were: loyalty to the Torah (both the Bible and the oral law), to the Land of Israel, and to the state of Israel. 
Although, over the years, Mafdal experienced many smaller and larger splintering events (1984, 1999, 2009, 2019, etc.), it has remained the political cornerstone of the RZS.

8 Until 1977, the number of seats ranged from ten to twelve, and then decreased to four to nine after massive shifts of voters to Likud or to splinter factions that did not cross the electoral threshold.

9 Unlike Bennett, Shaked is not religious but secular, but she holds right-wing views that enabled her to climb very rapidly to a leadership position in this mainly RZS party. This formerly improbable development (in particular because Shaked is also female, a rather uncommon characteristic in Orthodox parties in Israel) was also an outcome of this party's strategy to expand its constituency. In Hebrew, Yamina means "rightward", signaling the party's political direction.

11 The (SPSS) data files of all surveys referred to in this article can be found in the Israel Democracy Institute's data bank DataIsrael at https:/ / dataisrael.idi.org.il, accessed on 14 February 2022.

In recent years, the RZS has been influenced to a significant extent by the American right-wing/libertarian worldview. Among the vehicles through which this ideology has entered Israel's public political discourse are bodies such as the American TIKVA Fund; see https: / / tikvahfund.org/about, accessed on 14 February 2022.

An umbrella organization of municipal councils of Jewish settlements in the West Bank.

See https:/ /en.idi.org.il/media/13030/margins-to-fore-final.pdf, accessed on 14 February 2022, (Yair 2019).

This issue has been a sore point in the Israeli public discourse, particularly since Aharon Barak, president of the Supreme Court from 1995 to 2006, declared his constitutional revolution. Justice Barak promoted the view that the traditional doctrine of justiciability inappropriately and unnecessarily limits the matters with which the court deals. Hence, he pursued a judicial activist approach whereby the court was not required to limit itself to judicial interpretation and was permitted to fill the gaps in the law through the judicial legislation of common law.

16 One of the Jewish Power Party's positions is that the values of the Jewish state should accord with the Halacha (religious code) and the regime should be a Jewish democracy, which will uphold the interests of the Jewish nation-state as a cardinal value, thereby rejecting any universal values (https://he.wikipedia.org/wiki/\%D7\%A2\%D7\%95\%D7\%A6\%D7\%9E\%D7\%94_\%D7\%9 9\%D7\%94\%D7\%95\%D7\%93\%D7\%99\%D7\%AA\#cite_note-1, accessed on 14 February 2022). The heading of the Noam Party's platform was: "Jewish character for the state of Israel and the removal of foreign influences from the government system" (https://noamparty.org.il/\%D7\%A2\%D7\%A7\%D7\%A8\%D7\%95\%D7\%A0\%D7\%95\%D7\%AA, accessed on 14 February 2022).

https:/ /www.idi.org.il/media/12268/\%D7\%94\%D7\%99\%D7\%9E\%D7\%99\%D7\%9F-\%D7\%94\%D7\%97\%D7\%93\%D7\%A9-\%D7 $\% 9 \mathrm{E} \% \mathrm{D} 7 \% \mathrm{~A} 6 \% \mathrm{D} 7 \% \mathrm{~A} 2 . \mathrm{pdf}$, accessed on 14 February 2022. (In Hebrew)

18 Nevertheless, when she was justice minister, Shaked repeatedly attacked the Supreme Court for what she considered its excessively liberal spirit and openly sought to change its composition by nominating new, conservative judges.

https: / / www.srugim.co.il/541038-\%D7\%90\%D7\%99\%D7\%AA\%D7\%9E\%D7\%A8-\%D7\%91\%D7\%9F-\%D7\%92\%D7\%91\%D7\%9 9\%D7\%A8-\%D7\%AA\%D7\%95\%D7\%A7\%D7\%A3-\%D7\%94\%D7\%97\%D7\%9C\%D7\%98\%D7\%94-\%D7\%9E\%D7\%91\%D7\%99\%D7 \%A9\%D7\%94, accessed on 14 February 2022.

21 https://www.srugim.co.il/519154-\%D7\%A1\%D7\%9E\%D7\%95\%D7\%98\%D7\%A8\%D7\%99\%D7\%A5-\%D7\%90\%D7\%99\%D7\%9F\%D7\%97\%D7\%95\%D7\%91\%D7\%94-\%D7\%9C\%D7\%A6\%D7\%99\%D7\%99\%D7\%AA-\%D7\%9C\%D7\%A4\%D7\%A1\%D7\%A7-\%D7 \%91\%D7\%99\%D7\%AA-\%D7\%94\%D7\%9E\%D7\%A9\%D7\%A4\%D7\%98, accessed on 14 February 2022.

\section{References}

Andy, Rav Yoav. 2021. Smotrich and Ben Gvir in the Knesset: The End of Religious Zionism. Maariv, March 25. Available online: https:/ / www.maariv.co.il/journalists/opinions/Article-829853(accessed on 14 February 2022). (In Hebrew)

Ben, Nun Pazit, Gizem Arikan, and Allon Vishkin. 2021. Religion and Democratic Commitment: A Unifying Motivational Framework. Advances in Political Psychology 42: 75-108. [CrossRef]

Cohen, Asher. 2005. Religious Zionism and the National Religious Party in the 2003 Elections: An Attempt to Respond to the Challenges of Religious, Ethnic, and Political Schism. In The Elections in Israel: 2003. Edited by Asher Arian and Michal Shamir. New Brunswick: Transaction Books, pp. 187-213.

Cohen, Asher. 2011. The Splintered Camp: Religious Zionist Parties in the 2009 Elections. In The Elections in Israel 2009. Edited by Asher Arian and Michal Shamir. London: Routledge, pp. 69-92.

Cohen, Asher, and Menahem Lazar. 2019. Electoral Choice and Religion: Israel, Oxford: Oxford Research Encyclopedia of Politics. [CrossRef]

Don Yehiya, Eliezer. 2014. Messianism and Politics: The Ideological Transformation of Religious Zionism. Israel Studies 19: 239-63. [CrossRef]

Douek, Daniel. 2016. Lawmaker Backs Segregated Jewish, Arab Maternity Wards. The Times of Israel, April 5. Available online: https://www.timesofisrael.com/lawmaker-backs-segregated-jewish-arab-maternity-wards(accessed on 14 February 2022).

Finkelstein, Ariel. 2021. The National Religious Society in Data. Jerusalem: Ne'emanei Torah Va'Avoda. 
Hermann, Tamar. forthcoming. A Conditional Partnership: Jews and Arabs, Israel 2021. Jerusalem: Israeli Democracy Institute.

Hermann, Tamar, Gilad Be'ery, Ella Heller, Chanan Cohen, Yuval Lebel, Hanan Mozes, and Kalman Neuman. 2014. National Religious Sector in Israel. Jerusalem: Israeli Democracy Institute.

Hermann, Tamar, Or Anabi, Yaron Kaplan, and Inna Orly Saposnikova. 2021. The Israeli Democracy Index. Jerusalem: Israeli Democracy Institute.

Kastman, Hayim. 2020. The Hyphen Cannot Hold: Contemporary Trends in Religious-Zionism. Israel Studies Review 35: 154-74.

Kaye, Alexander. 2013. Democratic Themes in Religious Zionism. SHOFAR 31: 8-30. [CrossRef]

Kempinsky, Aharon, and Shmuel Sandler. 2020. The Religious Parties in the Netanyahu Era: The Politics of Israelization. In Israel under Netanyahu: Domestic Politics and Foreign Policy. Edited by Robert O. Freedman. New York: Routledge, pp. 74-90.

Navon, Rav Haim. 2021. A Small State for a Great People. Tel Aviv: Yediot Aharonot Books. (In Hebrew)

Pew Research Center. 2016. Israel's Religiously Divided Society. March 8. Available online: https://www.pewforum.org/2016/03/08 / israels-religiously-divided-society (accessed on 14 February 2022).

Rubin, Aviad. 2014. Bifurcated Loyalty and Religious Actors' Behaviour in Democratic Politics: The Case of Post-1967 Religious Zionism in Israel. Religion, State and Society 42: 46-65. [CrossRef]

Sadan, Rav Eli. n.d. Who Are You Religious Zionism: Queries from Left and Right. Available online: https://www.bneidavid.org/ DocsUpload/010270/Doc_10270.pdf (accessed on 13 February 2022). (In Hebrew)

Sagi, Avi, Dov Schwartz, and Batia Stein. 2018. Religious Zionism and the Six-Day War: From Realism to Messianism. London: Routledge. Schwartz, Dov. 2002. Faith at the Crossroad: The Theological Profile of Religious Zionism. Leiden: Brill.

The Times of Israel . 2021. Smotrich Pans Bennett: 'A Government with Abbas Is Like a Government with Hamas'. The Times of Israel, April 28. Available online: https://www.timesofisrael.com/liveblog_entry/smotrich-pans-bennett-a-government-with-abbas-islike-a-government-with-hamas(accessed on 11 February 2022).

Yair, Sheleg. 2019. From Margins to the Fore? Religious Zionism and the Israeli Society. Jerusalem: Israeli Democracy Institute.

Yuchtman-Yaar, Ephraim, Yasmin Alkalay, and Tom Aival. 2018. Effects of Religious Identity and Ethnicity on the Israeli Electorate. Israel Studies Review 33: 1-12. [CrossRef] 